\section{Governance, choice and the global market for mental health}

Sir: In their guest editorial for the August issue of International Psychiatry, Philip Sugarman and Andrew Kakabadse (2011) make interesting observations on how to improve state healthcare through patient choice, and how to develop an attractive alternative to monopolised state provision. Understandably, their focus was on mental health. They point out that the independent sector has, in the UK, increasingly invested in mental healthcare homes and hospitals.

The sector I work in - secure care and highly specialised treatment for people with intellectual disabilities, many of whom have forensic backgrounds - has perhaps recorded one of the largest growth rates of independent-sector role provision and expertise in recent years.

The 13th Biennial Report of the Mental Health Act Commission (2009) revealed that, in 1998, of individuals with an intellectual disability detained in hospitals, $15 \%$ were within the independent sector. This had grown to $46 \%$ of individuals ( 545 of 1184) by 2008. Moreover, in 2007/8 a total of 67 section 37 hospital orders were made (restricted and unrestricted), and 42 of these individuals were placed within the independent sector.

Collectively, the UK independent sector has immense knowledge of how best to provide tailormade and highly specialist care to this complex patient group, and offers this expertise internationally.

However, as Sugarman and Kakabadse note, there are political 'tensions' between public and private UK providers which stifle collaboration and debate over what services best meet patient needs. These tensions have, in turn, led to the independent sector being consulted only at a superficial level about the development of services for this patient group. I believe we must continue to emphasise the message that, for both mental healthcare and intellectual disability, independent care is funded from the National Health Service (NHS) or Social Services, not by the individual receiving care. The independent sector works in clinical partnership with the NHS. This cooperative relationship represents an important component of market diversity.

Actively promoting this message will both help defuse political tensions and enable the public to understand more clearly how the independent sector can provide effective and high-quality services which are both overseen by the NHS and free to the individual at the point of service delivery.

\section{Claire Royston MB ChB MSc FRCPsych}

Group Medical Director, Four Seasons Health Care, UK, email claire.royston@careprinciples.com

Sugarman, P. \& Kakabadse, A. (2011) Governance, choice and the global market for mental health. International Psychiatry, 8, 53-54.
Contents of the African Journal of Psychiatry (affiliated journal)

Volume 14 Number 5 November 2011

\section{From the Editor}

341 End of year message C. P. Szabo

\section{Guest editorial}

343 The future of old age psychiatry in Africa S. van Heerden, R. Uwakwe, F. Potochnick

351 Pan African Network of People with Psychosocial Disabilities

\section{Review articles}

355 Psychiatric genetics in South Africa: cutting a rough diamond

G. E. B. Wright, D. J. H. Niehaus, L. Koen,

B. I. Drögemöller, L. Warnich

367 Family therapy for schizophrenia: cultural challenges and implementation barriers in the South African context

L. Asmal, S. Mall, J. Kritzinger, B. Chiliza, R. Emsley, L. Swartz

\section{Original articles}

372 Methamphetamine use and sexual risk behaviour in Cape Town, South Africa: a review of data from 8 studies conducted between 2004 and 2007

C. D. H. Parry, A. Plüddemann, B. Myers, W. M. Wechsberg, A. J. Flisher

377 Profile of clinically-diagnosed dementias in a neuropsychiatric practice in Abeokuta South-Western Nigeria

G. Amoo, R. O. Akinyemi, L. U. Onofa, J. O. Akinyemi, O. Baiyewu, A. O. Ogunlesi, A. Ogunniyi

383 Risky behaviour and psychosocial correlates in adolescents - is there $a$ link with tuberculosis?

H. Geldenhuys, K. Sorsdahl, F. Kafaar, M. Hatherill, W. A. Hanekom, D. J. Stein, H. Mahomed

388 Functional status and its associated factors in Nigerian adolescents with bipolar disorder M. O. Bakare, A. O. Agomoh, J. Eaton,

P. O. Ebigbo, J. U. Onwukwe

392 Children with sickle cell disease who are experiencing psychosocial problems concurrently with their mothers: a Nigerian study

M. F. Tunde-Ayinmode

\section{Scientific letter}

406 Pseudophaeochromocytoma associated with clozapine therapy: a case report

O. Akinsola, K. Ong

\section{Letter to the Editor}

410 Poly-pharmacy in psychiatry: a debatable contemporary practice? Not much evidence O. Prakash

\section{Movie review}

412 The Beaver 